\title{
The Second Concept of Friendship
}

Evgeny Roshchin, Friendship among Nations: History of a Concept. Manchester University Press. 2017. 254 pages. ISBN 9781526116444.

\section{Ere Pertti Nokkala, Georg-August-Universität Göttingen}

Roshchin's temporally expansive study seeks to recover a lost perspective on friendship in international relations. His original argument is that contractual and political conception of friendship among nations was redescribed during the seventeenth- and especially eighteenth-century. Since then the ethical and normative concept of friendship has dominated the discourse and practice of international diplomacy. By recovering the "lost" concept of political friendship Roshchin gives us an opportunity to reflect on alternative ways of conceptualising international relations.

In agreement with Quentin Skinner Roshchin notes that the act of recovering a lost concept is in itself political "in the sense that it demonstrates how the past might inform our own thinking or how concepts and institutions forged in past ideological battles might be constitutive of policies made in the present. In this way it reveals contingency of political beliefs an identifies alternatives that can help us reflect upon and reassess today's prevailing social conventions and their normative agendas". (p. 16) In this sense the book bears resemblance to Skinner's Liberty before Liberalism (1998), where the author sought to recover the largely neglected "third concept" of liberty. Roshchin accomplishes a comparable act in respect of friendship. This political act is a way to counter the charge of antiquarianism often levied on historians of political thought following the premises of "Cambridge School". Not unlike Skinner, Roshchin does not simply give readily ruminated answers, but asks the reader to reflect on past perspectives, which encourages the readers to do the thinking themselves.

The introduction draws out the main unifying preoccupations of the chapters and reflects on methodological choices of the author. The methodological framework of the study has been inspired by the rapprochements between the "Cambridge School" and Begriffsgeschichte. The fruitfulness of combining contextualist, rhetorical and diachronic approaches was suggested already in the 1990s most prominently by Melvin Richter and Kari Palonen. This approach has been characteristic to the political scientists and conceptual historians trained at the University of Jyväskylä, Finland. This is where Roshchin completed his doctoral studies in 2009. The influence of Jyväskylä preponderates in the book's approach and analytical objectives. It is done with great precision and self-reflection. Roshchin recognises also the limits of the approach. 
He admits that "In assembling a number of discursive episodes in this study, I have made an attempt to combine contextualist analysis with a diachronic perspective on conceptual usage and change. Certainly, this combination could not have been achieved at no cost to both components" (p. 222). This high level of self-reflection and-criticism is typical for the study in general and perhaps it is exactly this quality that that has allowed the author to write a book that is a major contribution to several fields of study.

The book is divided into five thematic chapters. Chapter 1 deals with the ambivalences of ancient friendship recovering a usually overlooked concept of friendship amicitia, which Roshchin regards as the "foundation" of political friendship. Whereas the better-known philia served as basis for the ethical concept of friendship, amicitia was the basis for friendship of utility, which promised of benefits for participating parties. Roshchin identifies the conventional usages and the range of political practices that the friendship of utility helped to explain in ancient and medieval worlds. According to Roshchin, the "perspective of contractual and conditional friendship, offers us a grip on series of the key diplomatic practices in the classical world". (p. 55).

Chapter 2 on friendship in early modern political and juridical discourses is an exploration of the contractual and political understanding of friendship that fell into oblivion in the formative period of modern international politics. This chapter analyses sixteenth- and seventeenth- century legal and political debates in which the concept of political friendship was used as an argument. The chapter shows that the concept of political friendship was not a mere philosophical speculation, but it was widely used as well in historical and juridical discourses as in diplomatic practice. In the latter it was deployed in treatises, which specified binding obligations concerning trade, alliances, neutrality and territorial integrity. In this context it is important to note that Roshchin does not argue to be recovering a "tradition" of political friendship or lost "foundations" of international society. Rather, his aim in the chapter is to demonstrate the importance of the concept of political and contractual friendship in the writings of early modern authors.

Chapter 3 examines the ethics of friendship in early modern diplomacy that later became predominant. The chapter shows that the change from political, conditional and contractual friendship to ethical and normative friendship was not a linear chronological change where older political concept was replaced by a new ethical and normative one. On the contrary, as this chapter demonstrates Humanists possessed the highly moralised and normative concept of friendship and political and contractual concept simultaneously.

Chapter 4 is the key chapter of the book because it examines the reasons to why the concept of political contractual and conditional friendship slowly disappeared from learned philosophical, juridical and political discourse, and consequently from the diplomatic practice of legal statements and internation- 
al treaties. Roshchin gives a special role in this respect to the debate among natural law thinkers on natural condition of men. The conceptual shift started as a reaction to Thomas Hobbes' (1588-1679) notion of state of nature as a state of war by Samuel Pufendorf (1632-1694), who advocated natural sociability of men. Pufendorf's train of thought concerning friendship culminated in the writings of Christian Wolff (1679-1754) and Emer de Vattel (1714-1767). Roshchin argues that he actual conceptual change, a turn in conventional arguments about friendship was to a great extent a redescription of friendship by the last-mentioned two major eighteenth-century natural lawyers. Here one needs to be cautious - and I do believe that Rochshin is - to avoid falling back to the outdated conception where eighteenth-century German natural law is held "apolitical". In this interpretation, which is a variation of the out-dated Sonderweg-thesis, Christian Wolff is interpreted as an advocate of escape from politics to administration. However, natural law in itself - also in the case of Wolff - was essentially a political theory.

At the end of his key chapter Roshchin states that the debates among natural lawyers were only one of the factors contributing to conceptual change. $\mathrm{He}$ asserts: "It is important to remember that the valorisation of ethical perspective on friendship and the simultaneous marginalisation of its political regulatory functions took place against a background of an emerging international order that brought about institutions such as state sovereignty, international law and the balance of power. In fact, demand for contractual friendship might have decreased due to the growing specialisation of regimes of international trade, navigation, and so forth." (p. 173). And indeed, this might well be the case with Vattel, one of the key figures of Roshchin's argument. Vattel famously argued that

Europe forms a political system, an integral body, closely connected by the relations and different interests of the nations inhabiting this part of the world. It is not, as formerly, a confused heap of detached pieces, each of which though herself very little concerned in the fate of the others, and seldom regarded things which did not immediately concern her. The continual attention of sovereigns to every occurrence, the constant residence of ministers, and the perpetual negotiations, make of modern Europe a kind of republic, of which the members - each independent, but all linked together by the ties of common interest - unite for the maintenance of order and liberty. Hence arose that famous scheme of the political balance, or the equilibrium of power; by which is understood such a disposition of things, as that no one potentate be able absolutely to predominate, and prescribe laws to the others. ${ }^{1}$

For Vattel balance of power was a concept that served to promote a stable system of states, which again, would promote international peace. It was by no means a mere normative or ethical concept. It is a rather political concept, 
which may have served to make the concept of political friendship of marginal use. In Vattel we can also see that the "European republic" was not necessarily built on any specifically moral or ethical foundations. His case exemplifies that republican arguments did not necessarily rest on common ethical conception of unity or shared normative foundations, as Roshchin seems to suggest (p. 141). It could have been beneficial for the overall argument of the book to offer a treatment of Vattel's conception of balance of power and "European republic" in chapter 3 where these topics are discussed, given that he is the most influential advocate of the idea of balance of power doctrine and of the idea of a European republic. Even more so because Roshchin gives such a major role to Vattel in his argument. Now, Vattel is missing completely from Roshchin's treatment of balance of power (p. 128-129). Vattel's global impact on diplomatic practice would have even justified integrating him into Chapter 5 that traces the relations of friendship to institutions of international law and draws the consequences of the predominance of ethical and normative concept of friendship for the diplomatic practice. In this final chapter Roshchin concludes that the ethical and normative concept of friendship falls short in comparison with the pragmatic political friendship as an instrument for analysing diplomatic friendship.

Throughout the work Roshchin shows mastery of his primary and secondary sources and of their contexts. His comment about the difficulty of combining contextualist approach with a diachronic perspective turns out to be a very modest statement. Roschchin masters the temporally expansive aspects of this study, and simultaneously he is admirably well versed in the recent debates on individual authors. To take the example of Pufendorf; Roshchin is wellinformed of the latest state of research on Pufendorf's view on sociability and makes a well-informed choice, whose interpretation of Pufendorf to follow. Vattel might be an exception to this rule. However, the bulk of new literature on Vattel is so extensive that it might not have been realistic to take all of it into account in this study. In any case Vattel was a much more diverse thinker than one could assume based on reading Roshchin's contribution.

This original and well-researched book is a major contribution to at least three interrelated fields. First, it offers a genealogy of the concept of friendship from ancient world to its present-day meanings. It is of interest to intellectual historians and conceptual historians. Secondly, by recovering a lost political and contractual meaning of friendship in international relations Roshchin invites scholars active in the field of IR to reflect on their positions. This reflection is made possible by questioning the present day's social practices and conventions, and their normative agendas. In particular, Roshchin moves the debate on friendship beyond prevailing normative and sceptical conceptions. Thirdly, the book has the potential of encouraging debates and new research in the field of international law. For good reasons Roshchin sees a link between 
his study and a field of international law that perceives law as a performative language game. This approach has been most prominently advocated by Friedrich Kratochwil and Nicholas Onuf. Roshchin's study may bring new light to the constructivist understanding of knowledge, international order, rules and law. The book avoids being antiquarian, while it manages to avoid unnecessary anachronisms. At the same time the author understands that certain amount of presentism is unavoidable. By challenging the predominance of sceptical and naturalist concepts of friendship in international relations Roschin enters the contemporary debates. He is not afraid to make use of conceptual history to accomplish a pivotal contribution to understanding our contemporary world order.

\section{Endnotes}

1 Emer de Vattel, The Law of Nations, or, Principles of the Law of Nature, Applied to the Conduct and Affairs of Nations and Sovereigns, with Three Early Essays on the Origin and Nature of Natural Law and on Luxury, ed. with an Introduction by Béla Kapossy and Richard Whatmore (Indianapolis, 2008), p. 496. 